\title{
ADORA1 Gene
}

National Cancer Institute

\section{Source}

National Cancer Institute. ADORA1 Gene. NCI Thesaurus. Code C38609.

This gene is a critical biological mediator of several physiological functions. 